\title{
Evaluation of UIN North Sumatra E-Learning Program During the Covid-19 Period
}

\author{
Usiono $^{* 1}$, Salim $^{2}$, Zunidar ${ }^{3}$, Ahmad Taufik Al Afkari Siahaan ${ }^{4}$ \\ State Islamic University of North Sumatra, Medan, 1,2,3,4 \\ Email: usiono@uinsu.ac.id ${ }^{* 1}$, salim@uinsu.ac.id², zunidar@uinsu.ac.id ${ }^{3}$, \\ ahmadtaufikalfkarisiahaan@uinsu.ac.id ${ }^{4}$
}

\begin{abstract}
Pandemic Covid-19 requires online learning (E-Learning) at every tertiary institution, including UIN North Sumatra (UIN-SU) Medan. The readiness of institutions and campus academicians in facilitating students is not a major problem for UIN-SU Medan, because pre-coleaders 19 leaders issued a learning system policy of $70 \%$ face-to-face and 30\% e-learning. This paper aims to evaluate the UIN-SU Medan e-learning program during the COVID 19. This evaluation effort was carried out using a Context, Input, Process, \& Product (CIPP) study. This research criterion is a standard of compatibility between expectations and reality. Through interviews, observations, documentation, and dissemination of data obtained questionnaires, for further analysis using reduction techniques, data presentations, and concluding. The findings of this research indicate that the UINSU Medan e-learning program is well implemented, although it does not display significant changes, this can be seen from (1) context: elearning learning provides easy access to student learning and is accompanied by policies that follow government regulations and survive the development of technology; (2) input: Online learning system; (3) process: pre-covid19 70\% face-to-face \& 30\% e-learning, covid19 period 100\% e-learning; (4) product: lectures continue to run smoothly, and students can attend lectures from various places. Even so, there are obstacles in the form of internet network disruption, limitations on student quotas, and system downtime that require maintenance efforts.
\end{abstract}

Keywords: CIPP, Evaluation, E-Learning.

\begin{abstract}
Abstrak
Pandemi Covid-19 menuntut pembelajaran online (E-Learning) di setiap perguruan tinggi, termasuk UIN Sumatera Utara (UIN-SU) Medan. Kesiapan institusi dan sivitas akademika kampus dalam memfasilitasi mahasiswa bukan menjadi masalah besar bagi UIN-SU Medan, karena 19 pimpinan pre-co-leader mengeluarkan kebijakan sistem pembelajaran $70 \%$ tatap muka dan $30 \%$ e-learning. Tulisan ini
\end{abstract}


bertujuan untuk mengevaluasi program e-learning UIN-SU Medan selama masa COVID 19. Upaya evaluasi ini dilakukan dengan menggunakan studi Context, Input, Process, \& Product (CIPP). Kriteria penelitian ini merupakan standar kesesuaian antara harapan dan kenyataan. Melalui wawancara, observasi, dokumentasi, dan penyebaran data diperoleh kuesioner, untuk selanjutnya dianalisis menggunakan teknik reduksi, penyajian data, dan penarikan kesimpulan. Temuan penelitian ini menunjukkan bahwa program elearning UIN-SU Medan terlaksana dengan baik, walaupun tidak menunjukkan perubahan yang signifikan, hal ini dapat dilihat dari (1) konteks: e-learning learning memberikan kemudahan akses belajar siswa dan bersifat disertai dengan kebijakan yang mengikuti peraturan pemerintah dan bertahan terhadap perkembangan teknologi; (2) masukan: Sistem pembelajaran online; (3) proses: pracovid19 70\% tatap muka \& 30\% e-learning, periode covid19 100\% elearning; (4) produk: perkuliahan tetap berjalan lancar, dan mahasiswa dapat mengikuti perkuliahan dari berbagai tempat. Meski begitu, terdapat kendala berupa gangguan jaringan internet, keterbatasan kuota mahasiswa, dan sistem downtime yang memerlukan upaya pemeliharaan.

Kata Kunci:CIPP, Evaluasi, E-Learning.

\section{INTRODUCTION}

Today's technological developments make changes in every line of life (Nurdyansyah, 2017; Jamun, 2018; Thombare \& Verma, 2008:1-38; Cerovsek, 2011:224-244; Pilkington, et.al., 2002:5-12). In the era of technological and information development led to the boundaries and extent of territory between countries without boundaries and boundaries (Piliang, 2012; Herawati; 2011; Middlehurst, 2002:134-155). What is happening in the hemisphere in the western world today, everyone can watch it directly through the privacy room, through the grip and index finger of each. Likewise, when you want to order a favorite menu at a particular restaurant, you don't need to go to the location, just look for it to be applied within seconds the food will arrive and be ready to be enjoyed (Wardiana, 2002; Petersen, 2009). In short, technology is very helpful in facilitating human activity.

The world of education today is also inseparable from the reach of technological developments, both basic education to higher education (Aslamiyah, et.al., 2019; Keengwe \& Onchwari, 2009). Since the administration and recruitment of students are done online, to the learning system which is also 
based on internet networks. The use of media and learning methods, to the evaluation system which is also online. Indeed, the use of technology in education can be analogous to using a double-edged knife. One side seems to be faster and more modern, but on the other side, there is also ineffectiveness (Suryadi, 2015; Elihami \& Saharuddin, 2018:1-8; Vickery, 2012). Because when using technology, various other possible disturbances can occur and divide the focus.

Specifically, the world of higher education has also long responded to technological developments. Many campuses have used E-learning based online lecturing systems and are considered successful. E-learning is an independent learning model that is facilitated through the use of information technology. If you want to quote expert opinions, then E-learning can be defined as a learning program delivered online or through the internet, including tutorials delivered on campus, workshops, short courses, and job guidance (Ruhe \& Zumbo, 2009:2; Alonso, et.al., 2005:217-235). E-learning is a form of information technology that is applied in education in the form of cyberspace. The term e-learning is more precisely intended as an effort to make a transformation of the learning process in schools or colleges into digital form which is bridged by internet technology (Munir, 2009: 169).

According to Munir (2009:15), E-learning is a form of information technology that is applied in education in the form of cyberspace. The term Elearning is more precisely intended as an effort to make a transformation of the learning process in schools or colleges into digital form which is bridged by internet technology. E-learning as a medium can combine various sources of teaching and learning materials in various forms which include learning objects, multimedia, web content, articles, slides, notes, tools, real-time learning, textbooks, and others. Apart from e-Learning, it can also include various forms of learning activities including, portfolios, problem-solving, project work, collaborative student assignments, and others. Forms of assessment in ELearning can be done through portfolios, online presentations, and reports (Mesiono, 2020; Bell \& Federman, 2013:165-185).

Learning with E-Learning is a policy that is expected to facilitate the implementation of learning programs that are prioritized at UIN North Sumatra as a program that leads to digitalization. The form of digitalization is included in the learning process conducted at UIN North Sumatra (Nasution, 2018). Din 
order to improve the quality of the learning process and to meet the demands of the development of information technology and communication, the UIN in North Sumatra officially adopted the use of E-Learning as an electronic-based learning media with Rector's Decree No. 153 in 2019.

The e-learning program is even more urgent when the COVID 19 outbreak (Iyer, et.al., 2020:718-722; Fordjour, et.al., 2020; Assingkily \& Miswar, 2020). This also requires $100 \%$ online learning in digital classes at UIN North Sumatra online. Chancellor Circular Letter Number B.07 / Un.11.R / BI3c / KS.02 / 03/2020, North Sumatra State Islamic University Medan (UIN SU) extends the online lecture process (in-network) or online until the end of the even semester of the academic year 2019/2020, precisely until July 11, 2020. This extension is based on one item of the Director-General of Islamic Education Circular Letter Number 697/03/2020 concerning Amendment to the Director-General of Islamic Education Circular Letter Number 657/03/2020 Regarding Prevention of Covid-19 Distribution (Corona) in the Islamic Religious College Environment.

In the learning process E-Learning conducted at UIN North Sumatra, Medan is joined by several faculties and 58 study programs. Based on a large number of study programs that need to be known, how the effectiveness of ELearning learning, especially in Islamic higher education which is the style of UIN North Sumatra Medan.

From the policy aspect, the Chancellor determined the use of E-learning through Rector's Decree number 153 in 2019about the Technical Guidelines for the Application of E-learning at the North Sumatra State Islamic University, Medan. Furthermore, North Sumatra UIN through Rector's Decree number 183 in 2019 established the management team of North Sumatra UIN E-learning.

E-learning used by the North Sumatra State Islamic University in Medan was developed through an Open Source application named Moodle (Modular Object-Oriented Dynamic Learning Environment) version 3.3. This application was deliberately chosen because it has features and functions that support a more complete learning process compared to other applications (Tim Penyusun, 2019:1). The development of E-learning at the North Sumatra State Islamic University in Medan was not intended to replace face-to-face in the beginning, but rather as a medium or learning aid that facilitated the student-oriented learning process. Thus the use of E-learning is a complement to the face-to-face learning process where lecturers can use E-learning while face-to-face activities 
continue. In the first year of application, the lecture system with E-learning is given a weight of $30 \%$, and face-to-face recovery with a weight or $70 \%$ time allocation.

In terms of implementation and management, the team works by compiling an E-learning usage manual for lecturers and students listed on the UINSU E-learning website: http://elearning.uinsu.ac.id. In addition to making guidebooks, several video tutorials are also provided to be a reference for lecturer and student users.

To support the learning process of E-learning so that the maximum results are needed evaluation of the program so that E-learning learning can be well directed (Mahmudi, 2011; Gunawan, 2011). Program evaluation is an activity to gather information about plans or policies that have been implemented to determine the achievement of plans that have been arranged and as a basis for decision making so that their effectiveness can be improved (Muryadi, 2017).

To increase the effectiveness of e-learning programs, the team also forms and trains an admin or operator group consisting of representatives of each study program. The purpose of forming this admin is to become a facilitator for students and lecturers in their respective study programs if they experience obstacles. This operator group was formed by creating a discussion group via Whatsapp (WA).

An existing program needs to be evaluated so that the program runs under the expected goals. The evaluation is not managerial, but evaluation with a scientific research model. Indeed, a policy should not be left alone after it is implemented. Once the implementation of the policy takes place next it needs to be checked. According to Khan (2005:380), that the evaluation of the E-learning program is carried out by analyzing the components including 1) planning, 2) design, 3) production, and 4) Evaluation. At least there are several policy evaluation targets as revealed by Syafaruddin (2008:88-89), namely (1) Determine all policies and assess policies in achieving goals and objectives; (2) Identifying successes and failures of policy components; (3) Acceptance of a strategic program that is the best contribution to the successful implementation of the policy, and (4) Assessment of unexpected side effects or unintended consequences of the policy effort. 
Evaluation can be seen as an increasingly important part of educational practice. Specifically, E-learning evaluation needs to be done conceptually, technically, and philosophically. The idea of evaluating E-learning should lead to evaluating the use of the principle of an approach that focuses on the utilization and illustrating the implementation process (Conole \& Oliver, 2007:216; Laurillard, ed. 2004). Program evaluation is the process of knowing whether educational goals have been realized. The definition which is more widely accepted by the public was put forward by two evaluation experts, namely Cronbach and Stufflebeam. Both suggested that program evaluation was an effort to provide information to be conveyed to decision-makers (Arikunto, et.al., 2014:5).

Several previous studies have also done the same thing with the theme carried in this study. Among them are evaluating the benefits of e-learning through the CSE-UCLA model (Diyana, 2017:280), Kirkpatrick's model which concludes the evaluation on the process of interaction, learning, and results (Hamtini, 2008:693), effective online learning applications in the education process (Dhanapal, et.al., 2019:43), commitment management as the implementation of the learning innovation function (Ismail, et.al., 2009:3).

The distinction in this research, which specifically will evaluate the Elearning program in the effectiveness of Islamic education at UIN North Sumatra Medan using the CIPP (Context, Input, Process, and Product) model. This needs to be done to become a treasure of new knowledge and input to the E-learning developer UIN North Sumatra Medan. Thus, several aspects which later have been going well, need to be maintained and improved. While other aspects that are not optimal can be evaluated and then corrected in the future.

\section{RESEARCH METHOD}

This study uses an evaluation study of the implementation of the Elearning program at UIN Sumatera Utara Medan in the context, input, process, and outcome components of which is more familiar with the abbreviation for context, input, process, and product (CIPP). Basically, this model was chosen with the main objective being to evaluate to make improvements and input to policyholders (Stufflebeam \& Shinkfield, 2007:331). This study aims to obtain information so that improvements can be made in the process of developing Elearning and its implementation. The research criteria in this evaluation are 
conformity standards (Miarso, 2004:207). That is, the measurement in the evaluation of this program is done by comparing the reality that exists in the implementation of the program with the size or criteria of how the implementation of the program should occur. The subjects involved included the head of the laboratory, lecturers, students, and E-learning managers. While the methods used in data collection are questionnaires, interviews, observations, and documentation.

Looking at the description above, the research framework is simply displayed in the scheme below:

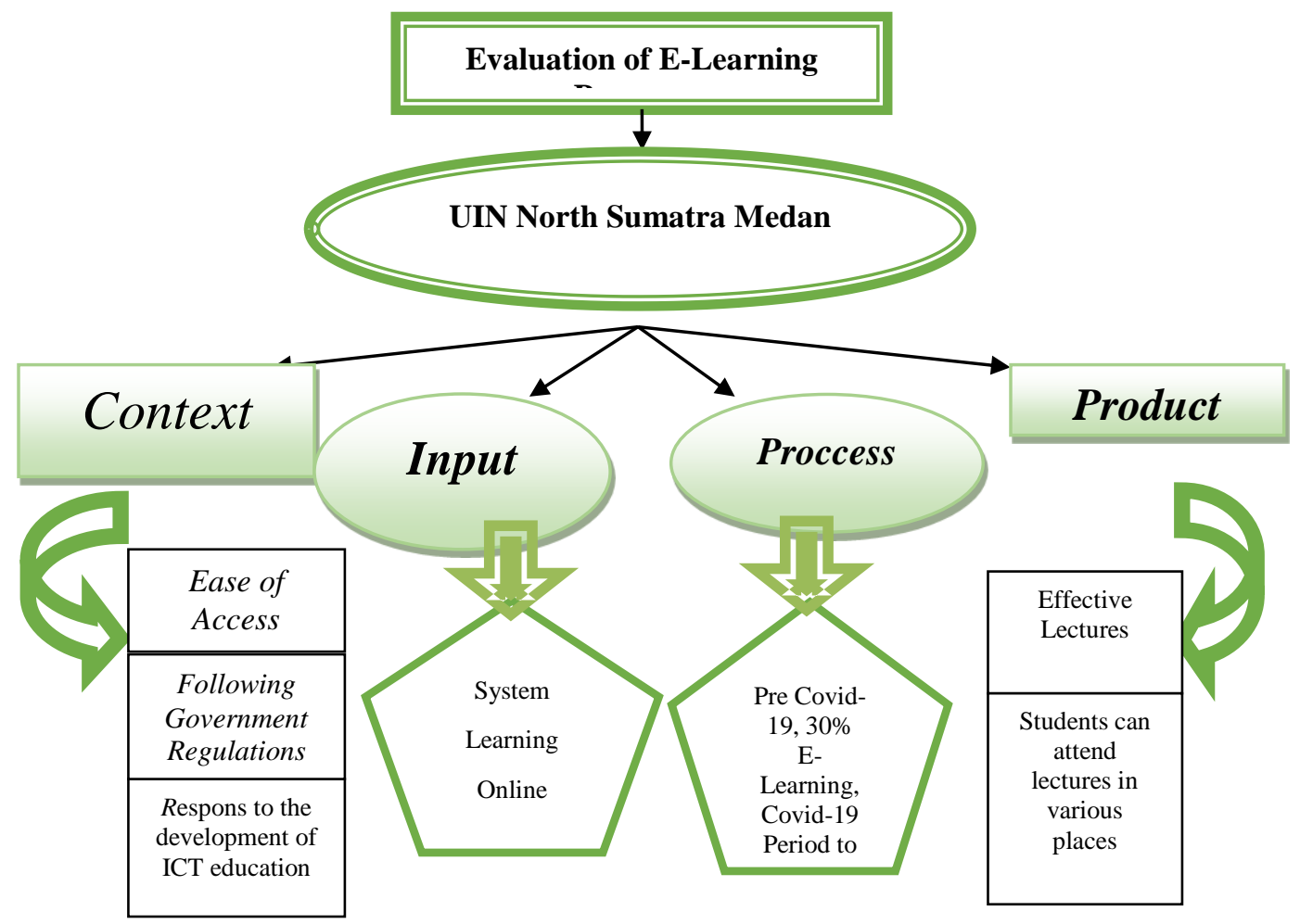

Scheme 1. Research Flow Framework

\section{FINDINGS AND DISCUSSION}

\section{Context Evaluation}

The context evaluation conducted in this study is the foundation and purpose of developing E-learning at UIN North Sumatra Medan. In line with this, Antonio, et.al., (2015:450-459) explained that the matter that underlies a current (contextual) event, includes the basics (foundation) and orientation (objectives) of a program/activity. Program evaluation in the aspect of context 
presents the basic principles of the product that will be found in a discussion (Yang, et.al., 2013:233-243).

The foundation of the E-learning development program at UIN North Sumatra Medan is carried out to answer the development of technology and information (Nasution, 2018). E-learning is a significant aspect of innovation in education that is driven by the power of technology-based platforms that offer an alternative and innovative learning environment compared to traditional learning models and is a technology and information-based innovation in education (Darmalaksana, et.al., 2020:1-12; Purwanto, et.al., 2020:1-12; Dewi, 2020). E-learning program at UIN Medan, North Sumatra, actually since 2014 it has been implemented but not as a whole. Only then in 2019 through the Chancellor's decision number 153 in 2019.

During a Covid-19 pandemic that is endemic globally (Cucinotta \& Vanelli, 2020:157-160; Garcia, et.al., 2020; Firman \& Rahayu, 2020), E-learning learning is a necessity. Government policies by regulating social distancing, keeping a distance, using masks, and keeping clean (hands) are ways to prevent the spread of COVID 19. Thus, the use of traditional classes as usual for learning activities is eliminated for one semester. Therefore, the Director-General of Islamic Higher Education issued a notice through a circular number 657/03/2020 concerning efforts to prevent the spread of Covid-19 (Corona) in the Islamic Higher Education Environment. With the e-learning system UIN SU Medan, it is also supported by the ease in lectures by providing other alternatives, namely: zoom meetings, jitsi meet, cloudx, video calls, google classroom, and WA.

Responding to the decree UIN North Sumatra Medan responded with a circular from the Chancellor number B: 06 / Un.11.R / BI3.c / KS.02 / 13/2020 about academic and non-academic policies related to preventing the spread of Covid-19 in the environment North Sumatra State Islamic University Medan. The letter explained that the teaching and learning system on the campus of UIN North Sumatra Medan uses E-learning. The E-learning in question is https://elearning.uinsu.ac.id.

Given the large number of students and the limitations of the internet network, then to maintain the effectiveness of learning, an E-learning system may also be done using Whatsapp (WA), E-mail, Telegram, Zoom Meeting, Video Conference, and so forth. It is not only about academic matters, but also 
administrative services which are carried out digitally based on the paperless office (PLO).

The purpose of E-learning based learning at UIN North Sumatra Medan is in the context of improving the quality of learning and meeting the demands of information technology development. Furthermore, it was explained that the provision of e-learning facilities since 2014 and continued to be upgraded until now was not intended to be a substitute for face-to-face learning activities, but rather as a medium that facilitates learning activities in the current technological era. According to the Chancellor's statement, this was also part of the digitization effort towards a world-class campus (World Class University).

In line with the above, the goal of E-learning is actually that students are expected to be active and responsible for building and managing their own learning experiences. In this case, the real learning center is in the students. learning by using E-learning can be said to be successful if it is supported by the use of appropriate strategies (Conrad \& Donaldson, 2004:7).

The following is displayed in the form of the front page of UIN North Sumatra UIN in Figure 1 below.

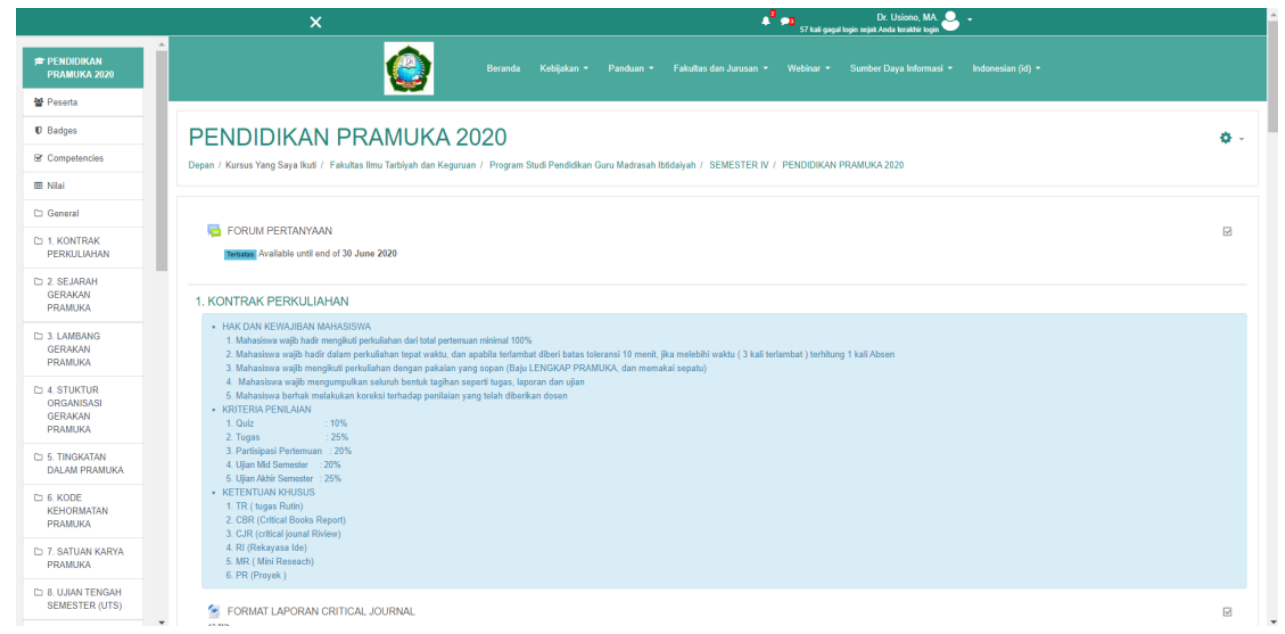

Figure 1. Front page of E-learning UIN North Sumatra.

Based on the picture above, it is understood that the readiness of UIN Sumatera Utara Medan in facilitating online learning for students is a sufficient duration in the period since 2014, and the quality of the display reflects online features that are neatly organized and easily accessed by the campus academic community. 
Observing the explanation above, it is understood that in context, the elearning program at UIN North Sumatra Medan was implemented effectively. This is seen from the circular of the chancellor who established online-based learning policies or regulations since 2014. Besides, the purpose of online learning planned from the beginning made them academics of UIN SU Medan not awkward with the Covid-19 pandemic.

\section{Input Evaluation}

Evaluation of inputs to be examined is related to planning, human resources (HR), infrastructure, and E-learning development budgets. This is based on the importance of looking at the input stage in a program. Because of the implementation of programs and products produced.

In this context, UIN SU Medan added cloud act meeting facilities from IDR 80,000,000 with 50 licenses. Besides, UIN SU Medan uses a zoom meeting with 300 usage periods for one year and a zoom meeting with 1000 participants with a usage period of one month with a fund of IDR 27,000,000. The main input stage is the online learning system. "Learning" in e-learning refers to "what": the course includes content and ways to help people learn it; and "why" refers to goals: to help individuals achieve educational goals or to help organizations build skills related to performance improvement (Clark \& Mayer, 2008:11). The purpose of e-learning is to build knowledge and skills that can be transferred through work related to organizational performance or to help individuals achieve personal learning goals and academic development.

Effective academic development results in increased e-teaching or blended learning which in turn leads to increased student learning outcomes (Kurniadi \& Mulyani, 2016). E-learning can contribute to a better understanding of emerging concepts and practical approaches used by academic staff and elearning developers.

It is important to foster lecturer knowledge about effective pedagogical practices for successful e-learning, and this is most effective when lecturers who start as online educators can experiment and develop their skills in a safe and reliable environment (Donnelly \& Sweneey, 2010:xviii). Thus, educators have stock in facilitating students to survive in the current era of learning, which is based online. 
The other side of traditional forms of teaching and learning is being changed in a very short time (Anggrawan, 2019:339-346). The use of ICTs in education continues to grow in popularity and usefulness. New models, platforms, applications, and more appear every day. In many ways it can help students who are at risk, even used to measure student progress, while others deal with legal issues.

The web has significantly helped increase access to educational opportunities. The ability to utilize all new technologies and apply them appropriately and will remain a key element in education. This paved the way for the emergence of new pedagogies (Kwan, et.al., 2008). Demands for the creation and development of this era which in turn produce innovative new work.

An important part of every educational practice is innovation, it can improve the way teachers engage with students (Asbari, et.al., 2020). This applies to all modes of learning and teaching, including technology-assisted learning and teaching. The innovation itself is challenging but can also bring solutions to various challenges related to the use of new educational technology at higher levels of education. But then technological innovation, when successful, in turn raises new challenges from an institutional perspective.

Questions that arise include how success is measured, whether it will be translated across disciplines, how it affects the use of existing technology, and how it can be applied across universities in ways that increase and increase efficiency and effectiveness, rather than simply adding another burden to teaching staff busy one (Asbari, et.al., 2020:6).

While innovation in the use of new educational technology is a positive thing, innovative activities need to be monitored because issues of compatibility, access, security, and training have an impact on what individuals can achieve using new technology. These problems are complicated by a variety of data sources that require individual access in the context of higher education (Asbari, et.al., 2020:8).

It is also estimated, at that time, that there were more than 1.5 billion web pages on the World Wide Web, and that number was growing by 1.9 million per day. Looking on the Web to gather the right content is a challenge, and the ability to search the Web is an important skill and must be measured. Ismail, et.al. (2018), successfully presents a series of coherent indexes to measure and 
characterize learners' Web skills. In short, and more importantly, to teach the smooth running of the Web, you must have several ways to measure what students possessed of these skills and their progress in obtaining them.

Success presents a coherent set of indexes to measure and characterize learners' Web skills (O'neil \& Farez, ed., 2003:xxi). In line with this, Guntoro, et.al., (2016), explained that evaluation of learning in the current era requires technological assistance as a tool to facilitate the work of educators, covering aspects of planning, teaching to assessment and supervision (supervision). The need for technology becomes an urgent matter in educational innovation, including e-learning programs in every tertiary institution such as those developed by UIN-SU Medan.

Based on the description above, it is understood that online learning is not just a new alternative to learning in the contemporary era, but is turning into a necessity for every tertiary institution. This is what underlies UIN-SU Medan with its digitalization program implementing e-learning learning on campus.

\section{Process Evaluation}

The evaluation process that will be examined is how is the compatibility between planning and the implementation of e-learning at UIN North Sumatra. As mentioned in the previous section, that the idea of developing an E-learning program in lectures has been around since 2014, but it was only fully implemented in 2019.

According to Mardianto, although e-learning programs have been initiated since 2014, policies as a legal basis and standard rules have not been developed. For this reason, since 2019 a policy has been established that underlies e-learning learning, and then rules are made in the form of e-learning guidelines at UIN-SU Medan.

The implementation of the e-learning program after the policy is determined based on the Rector's Decree No. 153 of 2019 received attention from some students. Because, there was a significant transition in the learning process applied by UIN-SU Medan, starting from 100\% face-to-face (traditional learning), then in 2019 learning was done face-to-face 70\% and online (e-learning) 30\%.

A learning transition is a form of innovation initiated by UIN-SU Medan as a form of developing learning systems that survive in the technological era (Budiman, 2017). Furthermore, Mardianto added that this transition period did 
not last long, learning using e-learning was tested with COVID-19, which made face-to-face learning temporarily nullified, fully $100 \%$ online or e-learning.

Supporting the statement above, Setemen (2010:207-214) said that the online learning system or e-learning is a form of developing an evaluation of contemporary learning. For this reason, the organizers of higher education institutions have to realize online-based learning processes, to respond to the times and technological sophistication.

Based on the description above, it is understood that UIN-SU Medan has made a good "first jump" before COVID-19. This can be seen from the initiative of the leadership of organizing online-based learning since 2014, then establishing its policies and standard rules since 2019 (70\% face-to-face, 30\% online), even in the co-19 period is seen as ready to do online-based learning with e-learning with $100 \%$ percentage. Furthermore, this effort is in line with the acceleration of digitalization that was jointly announced by the Chancellor and UIN-SU Medan academic community, to make UIN-SU Medan survive with technological developments.

\section{Evaluation of Results}

The evaluation of the results that will be seen in this study is how the participation of lecturers and students in using E-learning in lectures. Many theories say that internet-based learning, including e-learning, is effective. As revealed by Kwan, et.al., ed., (2008:17) that E-learning in addition to being effectively used in modern times can also improve the quality, scale, and breadth of learning reach.

Based on the findings, during Covid-19, the use of E-learning increased from several aspects: (1) An increase in the number of online students per day that could be monitored through the front page of the e-learning website; (2) Increasing the number of courses made in e-learning that can be evaluated through e-learning systems; Increasing the number of lecturers using e-learning.

Before the COVID-19 pandemic, around mid-March, users of Medan's UIN-SU e-learning were around 25,000. At present, there are 32,546 e-learning users, including lecturers and students. Related to the participation of lecturers using E-learning in lectures at UIN North Sumatra Medan can be seen in the form of tables and graphs as follows: 


\begin{tabular}{|c|c|c|c|c|c|c|c|c|c|c|c|c|}
\hline \multirow{3}{*}{ FAKULTAS } & \multirow{3}{*}{ PRODI } & \multicolumn{10}{|c|}{ EVALUASI JUMLAH MATAKULIAH YANG DIINPUT DI E-LEARNING } & \multirow[b]{3}{*}{ TOTAL MK } \\
\hline & & \multicolumn{10}{|c|}{$\begin{array}{l}\text { PER TANGGAL 15 JUNI } 2020 \\
\text { JUMLAH MATAKULIAH }\end{array}$} & \\
\hline & & SEM 1 & SEM 2 & SEM 3 & SEM 4 & SEM 5 & SEM 6 & SEM 7 & SEM 8 & PRODI & FAKULTAS & \\
\hline \multirow[t]{4}{*}{ FDK } & PMI & 3 & 1 & 0 & 0 & 0 & 0 & 2 & & 1 & 4 & 11 \\
\hline & KPI & 3 & 2 & 4 & 2 & 6 & 2 & 2 & & 3 & & 24 \\
\hline & $\mathrm{BPI}$ & 9 & 2 & 4 & 3 & 4 & 2 & 2 & & 3 & & 29 \\
\hline & $M D$ & 8 & 6 & 1 & 2 & 2 & 1 & 0 & & 1 & & 21 \\
\hline \multirow[t]{7}{*}{ FEBI } & AKS & 15 & 17 & 12 & 10 & 9 & 11 & 9 & & 5 & 20 & 108 \\
\hline & EKI & 13 & 25 & 21 & 16 & 14 & 8 & 17 & & 7 & & 121 \\
\hline & PERBANK & 16 & 12 & 21 & 19 & 16 & 14 & 12 & & 9 & & 119 \\
\hline & PERBANK & 0 & 0 & 0 & 0 & 0 & 0 & 1 & & & & 1 \\
\hline & AS & 6 & 7 & 5 & 12 & 10 & 5 & 3 & & 8 & & 56 \\
\hline & MANAJEM & 17 & 8 & 11 & 5 & 0 & 0 & 0 & & 4 & & 45 \\
\hline & PERBANK & 2 & 3 & 0 & 0 & 0 & 0 & 0 & & 1 & & 6 \\
\hline \multirow[t]{12}{*}{ FITK } & BKI & 37 & 17 & 31 & 8 & 28 & 17 & 16 & & 7 & 57 & 218 \\
\hline & $\mathrm{MPI}$ & 21 & 4 & 32 & 27 & 21 & 18 & 17 & & 10 & & 150 \\
\hline & PAI & 27 & 42 & 44 & 41 & 38 & 34 & 17 & & 21 & & 264 \\
\hline & PBA & 31 & 10 & 33 & 14 & 34 & 20 & 24 & & 1 & & 167 \\
\hline & PBI & 29 & 18 & 43 & 34 & 30 & 8 & 40 & & 11 & & 213 \\
\hline & PBIO & 28 & 16 & 26 & 14 & 13 & 15 & 6 & & 3 & & 121 \\
\hline & PGMI & 70 & 13 & 42 & 21 & 44 & 16 & 53 & & 3 & & 262 \\
\hline & PIPS & 20 & 12 & 13 & 32 & 18 & 5 & 3 & & 6 & & 109 \\
\hline & PIAUD & 41 & 20 & 35 & 22 & 24 & 24 & 18 & 1 & 6 & & 191 \\
\hline & PMM & 12 & 15 & 27 & 24 & 30 & 26 & 4 & & 10 & & 148 \\
\hline & PAI S2 & 1 & 15 & 2 & 0 & & & & & 3 & & 21 \\
\hline & MPI S2 & 1 & 9 & 2 & 0 & & & & & 1 & & 13 \\
\hline \multirow[t]{7}{*}{ FASIH } & PM & 2 & 1 & 1 & 2 & 0 & 1 & 2 & & 0 & 1 & 10 \\
\hline & SIYASAH & 5 & 0 & 1 & 0 & 7 & 1 & 1 & & 3 & & 18 \\
\hline & AS & 2 & 1 & 7 & 1 & 3 & 0 & 1 & & 0 & & 15 \\
\hline & MUAMAL & 5 & 2 & 0 & 2 & 4 & 1 & 5 & & 1 & & 20 \\
\hline & JINAYAH & 2 & 4 & 7 & 1 & 2 & 4 & 3 & & 0 & & 23 \\
\hline & STUDI HU & 5 & 0 & 1 & 0 & 0 & 0 & 0 & & 1 & & 7 \\
\hline & AS S2 & 2 & 2 & 0 & 0 & & & & & 0 & & 4 \\
\hline \multirow[t]{6}{*}{ FUSI } & AFI & 7 & 3 & 3 & 1 & 3 & 0 & 1 & & 5 & 6 & 29 \\
\hline & SAA & 0 & 2 & 3 & 4 & 1 & 0 & 1 & & 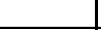 & & 11 \\
\hline & IAT & 11 & 3 & 6 & 4 & 1 & 1 & 1 & & 1 & & 28 \\
\hline & PPI & 1 & 4 & 0 & 2 & 0 & 2 & 1 & & + & & 10 \\
\hline & $\mathrm{IH}$ & 1 & 3 & 3 & 0 & 8 & 2 & 0 & & 1 & & 18 \\
\hline & IAT S2 & 0 & 0 & 0 & 0 & 0 & 0 & 0 & & & & 0 \\
\hline FKM & IKM & 21 & 17 & 31 & 15 & 26 & 13 & 9 & & 3 & 20 & 155 \\
\hline \multirow[t]{4}{*}{ FIS } & IP & 12 & 13 & 7 & 13 & 11 & 12 & 11 & & 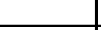 & 1 & 80 \\
\hline & IKOM & 9 & 4 & 7 & 4 & 9 & 4 & 1 & & 1 & & 39 \\
\hline & SPI & 1 & 3 & 5 & 2 & 5 & 0 & 2 & & 4 & & 22 \\
\hline & SAA & 10 & 3 & 2 & 7 & 7 & 1 & 1 & 1 & 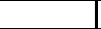 & & 32 \\
\hline \multirow[t]{5}{*}{ FSAINTEK } & ILKOM & 43 & 19 & 27 & 20 & 16 & 13 & 6 & 4 & 1 & 20 & 169 \\
\hline & $\mathrm{SI}$ & 25 & 27 & 19 & 23 & 22 & 21 & 9 & 7 & 10 & & 163 \\
\hline & MM & 4 & 15 & 5 & 18 & 10 & 12 & 3 & 1 & & 5 & 73 \\
\hline & $\mathrm{BIO}$ & 10 & 15 & 6 & 11 & 13 & 14 & 2 & 2 & 2 & & 75 \\
\hline & FIS & 13 & 17 & 9 & 19 & 18 & 12 & 6 & 4 & 3 & & 101 \\
\hline \multirow[t]{11}{*}{ PASCA } & $\mathrm{IH}(\mathrm{S} 2)$ & 0 & 0 & 0 & 0 & & & & & & & 0 \\
\hline & PEMI (S2) & 0 & 0 & 0 & 0 & & & & & & & 0 \\
\hline & EKI (S2) & 0 & 6 & 1 & 0 & & & & & 2 & & 9 \\
\hline & SHI (S2) & 0 & 0 & 0 & 1 & & & & & & & 1 \\
\hline & PEDI (S2) & 0 & 1 & 1 & 1 & & & & & & & 3 \\
\hline & KOMI & 0 & 0 & 0 & 0 & & & & & & & 0 \\
\hline & SHI (S3) & 0 & 0 & 0 & 0 & & & & & & & 0 \\
\hline & EKSYA (S3 & 0 & 3 & 1 & 0 & & & & & 5 & & 9 \\
\hline & KPI ((S3) & 0 & 0 & 0 & 0 & & & & & & & 0 \\
\hline & $\mathrm{AFI}(\mathrm{S} 3)$ & 0 & 0 & 0 & 0 & & & & & & & 0 \\
\hline & SIH (S3) & 이 & 0 & 0 & 0 & & & & & & & 0 \\
\hline
\end{tabular}

Table 1. Evaluate the number of subjects inputted at E-learning UIN North Sumatra Medan, as of July 15, 2020 


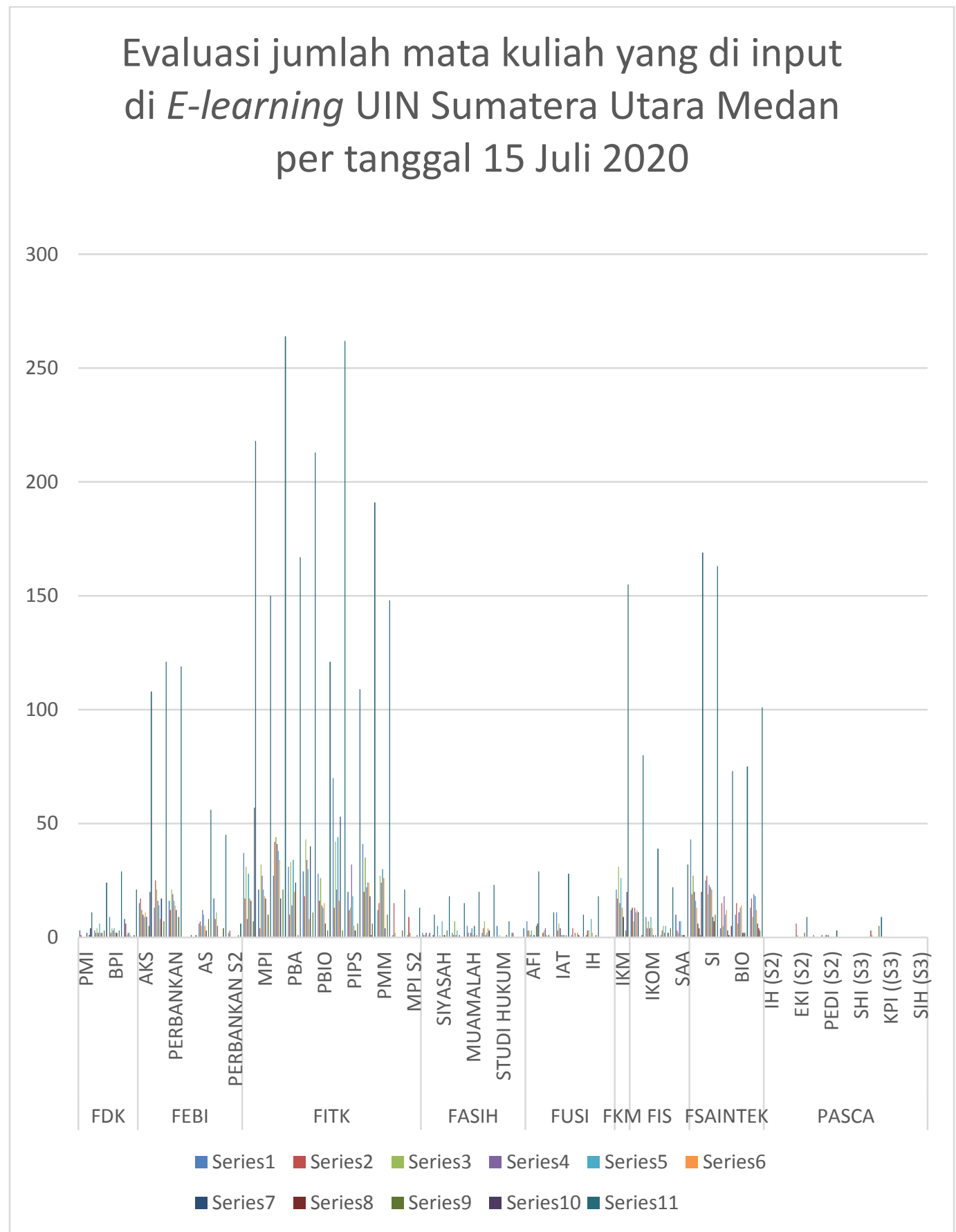

Figure 1. Evaluation graph of the number of subjects inputted on E-learning North Sumatra UIN Medan as of July 15, 2020

Based on the pictures and tables above, it can be analyzed that the implementation of the learning program is based on E-learning UIN North Sumatra Medan has not been maximally implemented. This can be seen from several faculties that still use E-learning as a learning medium. Like the Faculty 
of $D a^{\prime} w a h$ and Communication, the Faculty of Sharia and Law, the Faculty of Usuluddin and Islamic Studies, and Postgraduate.

For this reason, the e-learning development team accompanied the increased use and utilization of e-learning by using other applications as a complement to learning activities to facilitate communication between lecturers and students such as WhatsApp and Google Classroom.

Improvement efforts made by the development team e-learning UIN-SU Medan has been running well, as well as there are still obstacles in the implementation of the program. Based on the results of an interview with Halimah, one of the UIN-SU Medan Lecturers, the following interview excerpts:

The obstacle experienced in the implementation of E-learning is that not all students live in areas where internet access is easy, so some students are always left behind and some even do not attend lectures. (Interview with Halimah, Personnel of the e-Learning Development Team, on June $15^{\text {th }} 2020$, via WhatsApp)

In line with the above, MS, one of the students of the Faculty of Science and Technology said that he was frustrated by the obstacles and the use of UINSU e-learning that is rarely used by lecturers, instead turned to Zoom Meeting, Cloud Meeting, Video Conference, Whatsapp, whereas UIN- SU Medan has its platform in the form of e-learning. The following interview excerpts:

The use of E-Learning for learning during COVID-19 itself is rarely used. I do not know the reason for lecturers not using a homemade platform a la UINSU and prefer other online learning media.

Another complaint was also conveyed by AL, a FITK UIN-SU Medan student, following the interview excerpt:

In my personal opinion, the biggest obstacle is often the error learning or in repair, and the maximum data uploaded can only be $2 \mathrm{MB}$. So sometimes the lecturer asks that the assignment be posted while the size of the assignment data more than $2 M B$ will be difficult especially for some students who do not understand how to reduce the data size or size of a file. I have a friend who every time there is an assignment must ask for help from me or another friend to be helped to change, and sometimes if the same is opened or after a deadline where 
sometimes there are lecturers who make a task collection schedule only 2 hours after being distributed about the questions then no one is can help and finally the task does not become post or late.

Overcoming internet network barriers, lecturers use Zoom Meeting, Video Call, Google Classroom, Whatsapp. From the management aspect, UIN SU Medan provides facilities in the form of CloudMAX (to access Zoom Meeting for Lecturers and Staff).

Besides, some students convey the benefits of implementing online-based learning using e-learning and other platforms. As an interview excerpt delivered by PAI FITK UIN-SU Medan students. The following interview excerpts:

"In my opinion, the benefits of e-learning can facilitate online lecturing activities for lecturers and students, especially as a forum for the delivery of material and discussion material given by lecturers. What's more, online learning can be done in various places.

The above interview excerpt confirms that online lectures conducted by UIN-SU Medan are beneficial for students and lecturers alike because they can be accessed from various places. In line with this, Mustofa, et.al., (2019) said that lecturing online is beneficial for easy access to learning, it can even be an effort to reduce the disparity in the quality of higher education.

Based on the description above, it is understood that the use of UIN-SU Medan e-learning has some impacts in the form of online-based learning products with lectures still running effectively and students can take lectures from various places.

\section{CONCLUSION}

Based on the explanation above, it can be concluded that the UIN-SU Medan e-learning program is well implemented, although it does not display significant changes, this can be seen from (1) context: e-learning learning provides easy access to learning and is accompanied by policies that refer to government regulations and response to survival against the development of communication and information technology (ICT); (2) input: Online learning system; (3) process: pre-COVID 19 70\% face-to-face \& 30\% e-learning, covid19 
294 | TAZKIR: Jurnal Penelitian Ilmu-ilmu Sosial dan Keislaman

Vol. 07 No. 2 Desember 2021

period $100 \%$ e-learning with $78 \%$ achievements; (4) product: lectures continue to run smoothly, and students can participate in lectures from various places with some obstacles in the form of internet network disruption, student quota limitations and down systems that require maintenance efforts. 


\section{REFERENCES}

Al Aslamiyah, T., et.al. (2019). "Blended Learning dan Kemandirian Belajar Mahasiswa Teknologi Pendidikan" Jurnal Kajian Teknologi Pendidikan, 2(2). http://journal2.um.ac.id/index.php/jktp/article/view/7862.

Alonso, F., et.al. (2005). "An Instructional Model for Web-Based E-Learning Education with A Blended Learning Process Approach" British Journal of Educational Technology, 36(2): 217-235. https://doi.org/10.1111/j.14678535.2005.00454.x.

Anggrawan, A. (2019). “Analisis Deskriptif Hasil Belajar Pembelajaran Tatap Muka dan Pembelajaran Online Menurut Gaya Belajar Mahasiswa" MATRIK: Jurnal Manajemen, Teknik Informatika dan Rekayasa Komputer, 18(2): 339-346. https://doi.org/10.30812/matrik.v18i2.411.

Arikunto, S., Cepi, S., \& Jabar, A. (2014). Evaluasi Program Pendidikan: Pedoman Teoritis Praktis bagi Mahasiswa dan Praktisi Pendidikan. Jakarta: Bumi Aksara.

Asbari, M., et.al. (2020). "Hard Skills dan Soft Skills: Apa Membangun Inovasi Guru Sekolah Islam" Evaluasi: Jurnal Manajemen Pendidikan Islam, 4(1). http://e-journal.staima-alhikam.ac.id/index.php/evaluasi/article/view/362.

Assingkily, M.S., \& Miswar, M. (2020). “Urgensitas Pendidikan Akhlak Bagi Anak Usia Dasar (Studi Era Darurat Covid 19)" TAZKIYA, 9(2). http://jurnaltarbiyah.uinsu.ac.id/index.php/tazkiya/article/view/836.

Bell, B.S. \& Federman, J.E. (2013). “E-Learning in Postsecondary Education” The Future of Children, 23(1): 165-185. https://www.jstor.org/stable/23409493?seq=1.

Budiman, H. (2017). "Peran Teknologi Informasi dan Komunikasi dalam Pendidikan" Al-Tadzkiyyah: Jurnal Pendidikan Islam, 8(1). http://103.88.229.8/index.php/tadzkiyyah/article/view/2095.

Cerovsek, T. (2011). "A Review and Outlook for a 'Building Information Model' (BIM): A Multi-Standpoint Framework for Technological Development" Advanced Engineering Informatics, 25(2): 224-244. https://doi.org/10.1016/j.aei.2010.06.003.

Clark, R.C. \& Mayer, R.E. (2008). E-learning and the Science of Instruction. San Francisco: John Willey Son, Inc. 
Conole, G. \& Oliver, M. (2007). Contemporary Perspectives in E-Learning Research: Themes, Methods and Impact on Practice. USA: Routledge.

Conrad, R.M. \& Donaldson, J.A. (2004). Engaging the Online Learner: Activities and Resources for Creative Instruction. USA: Josssey-Bass.

Cucinotta, D. \& Vanelli, M. (2020). "WHO Declares Covid-19 a Pandemic" Acta Bio-Medica: $\quad$ Atenei $\quad$ Parmensis, $157-160$. https://doi.org/10.23750/abm.v91i1.9397.

Darmalaksana, W., et.al. (2020). "Analisis Pembelajaran Online Masa WFH Pandemic Covid-19 sebagai Tantangan Pemimpin Digital Abad 21" Karya Tulis Ilmiah (KTI) masa WFH Covid-19, UIN Sunan Gunung Djati Bandung: 1-12. http://digilib.uinsgd.ac.id/30434/.

Dewi, W.A.F. (2020). “Dampak Covid-19 Terhadap Implementasi Pembelajaran Daring di Sekolah Dasar" Edukatif: Jurnal Ilmu Pendidikan, 2(1). https://edukatif.org/index.php/edukatif/article/view/89.

Dhanapal, S., et.al. (2019). "XYZ Application as a Tool for Teaching and Learning in Institution of Higher Learning: an Exploratory Study", in Jurnal Pengurusan, Vol. LV.

Diyana, D.G.H. (2017). “Evaluasi Pemanfaatan E-learning dengan menggunakan Model CSE-UCLA", in Jurnal Cakrawala Pendidikan, Vol. XXXVI, No. 2.

Donnelly, R. \& Sweneey, F.M.C. (2010). Applied E-learning and E-teaching in Higher Education. New York: Information Science Reference.

Elihami, E. \& Saharuddin, A. (2018). “Peran Teknologi Pembelajaran Islam dalam Organisasi Belajar" Edumaspul: Jurnal Pendidikan, 1(1): 1-8. https://doi.org/10.33487/edumaspul.v1i1.34.

Firman, F. \& Rahayu, S. (2020). “Pembelajaran Online di Tengah Pandemi Covid19" Indonesian Journal of Educational Science, 2(2). https://ojs.unsulbar.ac.id/index.php/ijes/article/view/659.

Fordjour, C.O., et.al. (2020). "The Impact of Covid-19 on Learning-The Perspective of the Ghanaian Student" European Journal of Education Studies, 7(3). https://www.oapub.org/edu/index.php/ejes/article/view/3000.

Garcia, A.C., et.al. (2015). “An Empirical Study on M-Learning Adaptation: Learning Performance and Learning Contexts" Computers $\mathcal{E}$ Education, 82(1): 450-459. https://doi.org/10.1016/j.compedu.2014.12.007. 
Gunawan, I. (2011). “Evaluasi Program Pembelajaran” Jurnal Pendidikan, 17(1). http://e-journal.unipma.ac.id/index.php/JP/article/view/108.

Guntoro, D., et.al. (2016). "Pengembangan Model Supervisi Akademik Berbantuan E-Supervision Berbasis Web" Educational Management, 5(2). https://journal.unnes.ac.id/sju/index.php/eduman/article/view/12967.

Hamtini, T.M. (2008). “Evaluating e-learning programs: An adaptation of Kirkpatrick's model to accommodate e-learning environments", in Journal of Computer Science, Vol. IV, No. 8.

Herawati, E. (2011). “Komunikasi dalam Era Teknologi Komunikasi Informasi” Binus University Journal, 2(1). http://202.58.182.161/index.php/Humaniora/article/view/2955.

Ismail, M.D., et.al. (2009). “SMEs' Export Performance: The Effect of Learning Orientation and Innovativeness", in Jurnal Pengurusan, Vol. LIV.

Ismail, et.al. (2018). "Pengembangan Kompetensi Mahasiswa Melalui Efektivitas Program Magang Kependidikan" Edumaspul: Jurnal Pendidikan, 2(1): 124132. https://doi.org/10.33487/edumaspul.v2i1.48.

Iyer, P., et.al. (2020). "Impact of Covid-19 on Dental Education in the United States" Dent Educ, 84(1): 718-722. https://www.immagic.com/eLibrary/ARCHIVES/GENERAL/U_LONDON/ L040616L.pdf.

O'Neil, H.F.J. \& Farez, R.S. (ed.). (2003). Technologyu Application in Education: A Learning View. Lawrence Erlbaum Associates, inc.

Jamun, Y.M. (2018). “Dampak Teknologi Terhadap Pendidikan” Jurnal Pendidikan dan Kebudayaan Missio, http://jurnal.unikastpaulus.ac.id/index.php/jpkm/article/view/54.

Keengwe, J. \& Onchwari, G. (2009). “Technology and Early Childhood Education: A Technology Integration Professional Development Model for Practicing Teachers" Early Childhood Education Journal, 37(209). https://doi.org/10.1007/s10643-009-0341-0.

Khan, B. (2005). Managing E-Learning Strategies: Design, Delivery, Implementation and Evaluation. USA: George Washington University.

Kurniadi, D. \& Mulyani, A. (2016). "Implementasi Pengembangan Student Information Terminal (S-IT) untuk Pelayanan Akademik Mahasiswa" Jurnal Algoritma, 13(2). https://doi.org/10.33364/algoritma/v.13-2.437. 
Kwan, R., et.al. (ed.). (2008). Enhancing Learning Through Technology. New Jersey: World Scientific.

Kwan, R., et.al., (Ed.). (2008). Enhancing Learning Through Technology: Research on Emerging Technologies and Pedagogies. Singapore: World Scientific Publishing.

Laurillard, D. (2004). "E-Learning in Higher Education" From Changing Higher Education, ed. Paul Ashwin. https://www.immagic.com/eLibrary/ARCHIVES/GENERAL/U_LONDON/ L040616L.pdf.

Mahmudi, I. (2011). “CIPP: Suatu Model Evaluasi Program Pendidikan” AlTa'dib: Journal of Pesantren Education, 6(1). http://dx.doi.org/10.21111/attadib.v6i1.551.

Mesiono, M. (2020). “E-Learning Management of the State Islamic University of North Sumatera in Pandemic Covid-19", in International Journal of Advanced Science and Technology, Vol. XXIX, No. 5.

Miarso, Y.H. (2004). Menyemai Benih Teknologi Pendidikan. Jakarta: Prenada Media.

Middlehurst, R. (2002). "Variations on a Theme: Complexity and Choice in A World Ofborderless Education" Journal of Studies in International Education, 6(2): 134-155. https://doi.org/10.1177\%2F1028315302006002004.

Munir. (2009). Pembelajaran Jarak Jauh Berbasis Teknologi Informasi dan Komunikasi. Bandung: Alfabeta.

Muryadi, A.D. (2017). "Model Evaluasi Program dalam Penelitian Evaluasi" Jurnal Ilmiah Penjas (Penelitian, Pendidikan dan Pengajaran), 3(1). http://ejournal.utp.ac.id/index.php/JIP/article/view/538

Mustofa, M.I., et.al. (2019). “Formulasi Model Perkuliahan Daring Sebagai Upaya Menekan Disparitas Kualitas Perguruan Tinggi" Walisongo Journal of Information Technology, $1(2)$. http://www.journal.walisongo.ac.id/index.php/jit/article/view/4067.

Nasution, Y.R. (2018). "Penerapan Aplikasi Online Angket Persepsi Mahasiswa Terhadap Kinerja Dosen UIN Sumatera Utara Medan" Journal of Islamic Science and Technology, 3(2). http://jurnal.uinsu.ac.id/index.php/jistech/article/view/3158. 
Nurdyansyah, N. (2017). “Sumber Daya dalam Teknologi Pendidikan” Disertasi, Sidoarjo: Universitas Muhammadiyah Sidoarjo. http://eprints.umsida.ac.id/1625/.

Petersen, K. (2009). "Ease of Access: Suicide and Prevention" Journal Digital $\begin{array}{llll}\text { Research } & \mathcal{E} & \text { Publishing, }\end{array}$ https://ses.library.usyd.edu.au/bitstream/handle/2123/8130/DRPJournal_5p m_S1_2? sequence=1\#page=71.

Piliang, Y.A. (2012). “Masyarakat Informasi dan Digital: Teknologi Informasi dan Perubahan Sosial" Jurnal Sosioteknologi, 11(27). http://journals.itb.ac.id/index.php/sostek/article/view/1098.

Pilkington, A., et.al., (2002). “The Electric Vehicle: Patent Data As Indicators of Technological Development" World Patent Information, 24(1): 5-12. https://doi.org/10.1016/S0172-2190(01)00065-5.

Purwanto, A., et.al. (2020). “Studi Eksploratif Dampak Pandemi Covid-19 Terhadap Proses Pembelajaran Online di Sekolah Dasar" EduPsyCouns: Journal of Education, Psychologi, and Counseling, 2(1): 1-12. https://ummaspul.e-journal.id/Edupsycouns/article/view/397.

Ruhe, V. \& Zumbo, B.D. (2009). Evaluation in Distance Education and E-Learning: The Unfolding Model. New York: The Guilford Press.

Garcia, S., et.al. (2020). "Reduction in ST-Segment Elevation Cardiac Catheterization Laboratory Activations in the United States During Covid19 Pandemic" Journal of the American College of Cardiology. https://www.onlinejacc.org/content/accj/early/2020/04/07/j.jacc.2020.04.011.f ull.pdf?downloa.

Setemen, K. (2010). "Pengembangan Evaluasi Pembelajaran Online" Jurnal Pendidikan dan Pengajaran, 43(3): 207-214. https://ejournal.undiksha.ac.id/index.php/JPP/article/viewFile/124/118.

Stufflebeam, D.L. \& Anthony, J.S. (2007). Evaluations: Theory, Models and Applications. San Fransisco: Jossey-Bass.

Suryadi, S. (2015). “Peranan Perkembangan Teknologi Informasi dan Komunikasi dalam Kegiatan Pembelajaran dan Perkembangan Dunia Pendidikan" Informatika: Jurnal Ilmiah AMIK Labuhanbatu, 3(3). file://C:/Windows/system32/config/systemprofile/Downloads/219-509-1SM.pdf. 
Syafaruddin. (2008). Efektivitas Kebijakan Pendidikan: Konsep, Strategi, dan Aplikasi Kebijakan Menuju Organisasi Sekolah Efektif. Jakarta: Rineka Cipta.

Thombare, D.G. \& Verma, S.K. (2008). "Technological Development in the Stirling Cycle Engines" Renewable and Sustainable Energy Reviews, 12(1): 138. https://doi.org/10.1016/j.rser.2006.07.001.

Tim Penyusun. (2019). Panduan E-Learning UIN Sumatera Utara. Medan: UIN Sumatera Utara.

Vickery, G. (2012). "Smarter and Greener? Information Technology and the Environment: Positive or Negative Impacts?" International Institute for Sustainable Development. https://www.iisd.org/pdf/2012/com_icts_vickery.pdf.

Wardiana, W. (2002). “Perkembangan Teknologi Informasi di Indonesia" Seminar dan Pameran Teknologi Informasi FT Unikom Bandung Jawa Barat. http://eprints.rclis.org/6534/.

Yang, G., et.al. (2013). "The Effectiveness of Automatic Text Summarization in Mobile Learning Contexts" Computers \& Education, 68(1): 233-243. https://doi.org/10.1016/j.compedu.2013.05.012. 